\title{
Network Marketing and Supply Chain Management: Here to Stay
}

\author{
Raj Selladurai
}

School of Business and Economics, Indiana University Northwest, Gary, 46408, USA

\begin{abstract}
Network marketing, as a strategic tool of supply chain management, has been gaining popularity. This paper looks at the network marketing-supply chain paradigm, and analyses some of its implications. The network marketing paradigm has become more significant because of the growth/popularity of the internet, which provides a powerful impetus to the whole concept of effective network marketing-supply chain management. This mainly conceptual, theoretical study will also provide a practical perspective by looking at a few manufacturing and service companies that are implementing the network marketing-supply chain strategy model in some form. The study develops an effective network marketing-supply chain management model that uses network marketing and supply chain management as key strategies, and shows their positive impact on customer satisfaction and customer loyalty. This study contends that network marketing and supply chain management are here to stay!
\end{abstract}

Keywords Network Marketing, Sustainable Supply Chain Management, Customer Satisfaction, Customer Loyalty

\section{Introduction}

Network marketing, as a strategic tool of supply management, has been gaining popularity. This paper looks at the network marketing-supply chain paradigm, and analyses some of its implications. The network marketing paradigm has been grown in importance because of the popularity and the increased use of the internet, which provides a powerful impetus to the whole concept of effective network marketing-supply chain management. This mainly conceptual, theoretical study will also provide a practical perspective by looking at a few manufacturing and service companies that are implementing the network marketing-supply chain strategy model in some form. The study develops an effective network marketing-supply chain management model that uses network marketing and supply chain management as key strategies, and shows their impact on customer satisfaction and customer loyalty. The purpose of this study is to discuss the significance of network marketing and supply chain management and to show their impact on customer satisfaction and customer loyalty. This study contends that network marketing and supply chain management are here to stay!

Several business organizations across the globe have used a variety of network marketing strategies and

* Corresponding author:

rsellad@iun.edu (Raj Selladurai)

Published online at http://journal.sapub.org/mm

Copyright (C) 2012 Scientific \& Academic Publishing. All Rights Reserved integrated them into their operations in some creative ways to achieve great success. They have used network marketing strategies very effectively enabling network marketing's reputation and popularity to have increased tremendously in the United States and in the world over the last several decades. Recently, Warren Buffet's Berkshire Hathaway company provided a major boost to network marketing when it bought The Pampered Chef, a leading network marketing company. And Southern Living at Home, another successful network marketing leader in the home decorative industry, generated more than $\$ 100$ million a year for AOL Time Warner, its parent company at that time[1]. Network marketing has extended beyond the U.S. shores and other countries have begun to take a real close look at this "new" phenomenon. This American-style network marketing model has been referred to as the "new" paradigm which is being experimented with and implemented by many businesses and other organizational structures in the Japanese economy[2]. And even in China, the world's biggest market, several companies and many local people are getting into network marketing[3].

\section{Background Review}

\subsection{Importance of Network Marketing}

Network marketing, also more commonly referred to as direct sales or direct marketing or multilevel marketing and/or other similar concepts, is basically the direct distribution strategy of a product or service from the company to 
the consumers through building effective relationship marketing between distributors and customers. Typically, network marketing strategy is implemented via a structure or system in which the manufacturing company chooses to distribute its products and services directly to its customers through a network of distributors. This is done usually through a selective group of dynamic and highly motivated people outside the company (called distributors, dealers, affiliates, partners, etc.) who market the products and services directly to the consumers and get paid by the manufacturer for doing so. These distributors are also given the opportunity to develop and build their own independent business networks, usually called a downline or multi-level organizational structure, through recruiting, training, and inspiring others to duplicate their efforts and themselves. Products are sold mostly from outside the fixed retail locations and usually from the home, primarily through one-on-one personal contact and through product demonstrations. With the increasing popularity of the internet, several companies' dealers and representatives are using the internet to market their products, and are building their business networks by using proven lead generation systems in collaboration with specialized lead generation companies.

Network marketing or direct selling overall may also be referred to as an industry -- a fast growing, successful industry. In 2007 alone, the direct selling industry reported 30.8 billion in total sales in the US with a workforce of about 15 million involved in some way in this industry[4]. What makes network marketing so popular and unique? The one-to-one personalized, relationship marketing interaction that takes place between distributor and customer is the key to network marketing. Most people would prefer and choose to buy from someone whom they know, like, and trust - network marketing personifies this concept extremely well. People would generally prefer to buy their product/s from a local distributor - a friend, neighbor, associate, co-worker, peer or colleague, fellow member of a church, social club, etc. rather than from an impersonal corporate office or company sales office. Direct selling or network marketing promotes this personalized touch to selling and buying amongst distributors and customers. Recent studies showed that about 74 percent of Americans have purchased goods or services through the direct sales method. This is more than the number who have purchased through television shopping and on-line computer services combined. People seem to highly value the products available through direct selling channels and about 45 percent of Americans want to buy from direct sellers[5]. Direct selling seems to be increasingly used as a viable alternative or supplement to traditional marketing. As growth and expansion in the traditional retail, catalog, and online selling channels slow down and often stagnate, many companies are using direct selling to stimulate growth[6]. When integrated with new marketing strategies like viral marketing and social media networking, direct marketing focuses on leveraging the consumers' connections and relationships to maximize impact $[7,8]$.

Also, a major reason for network marketing's growth and popularity is the cost advantage that it provides. Cateora[9] has characterized channel maintenance costs as the margins, mark-ups, and commissions of channel members in the network. Reducing or eliminating the middlemen in the supply chain so as to allow for greater margins would be the ultimate goal of manufacturers and traders - has been so from the beginning of trade. The potential to increase profits by eliminating the intermediate channels of distribution is a strong motivating factor for the growth of direct marketing. Although network marketers often boast about their channel's efficiency in avoiding wholesalers and conventional retailers, this channel is not a totally low cost channel[10]. However, it still is a profitable source to the manufacturer as the channel has the ability to command a higher price for its products compared to similar products which are distributed through traditional retail stores[11].

The advantages in terms of capital requirement and cash flow implications that network marketing offers would contribute further to its attractiveness. This channel seems to symbolize the ideal, where the entire distribution network in the supply chain pays cash with orders and holds inventory at its own expense. For example, Mary Kay Cosmetics encourages its distributors to have a minimum of $\$ 600$ worth of inventory and this may be enhanced up to around $\$ 3000$ in order to support its customers. Also, Amway has generated significant cash flows from its operations by requiring its distributors to hold inventory (at least 3 to 8 weeks' stock) and pay upfront for their inventory items[10].

Network marketing also provides more control and promotes quicker action in the supply chain. Companies can easily communicate with the entire distribution network today through emails, online platforms and messages, telephone, and video conferences and can effectively manage the physical distribution of their products through company controlled warehousing. Hence, communication is fast and effective, which enables the introduction of new products quickly and efficiently through the distributors in the supply chain to their customers all over the country and even the world - in a relatively short time and at very lost costs. Further, network marketing stimulates fast action compared to traditional retail outlets in terms of product introductions, sales, after-sales service, handling returns, and prompt delivery of goods and services[12].

Network marketing also provides excellent coverage related to maximizing sales volume, market share, and market penetration[9]. Weitzen stated that network marketing companies can stimulate hypergrowth because they can effectively inform, educate, and persuade customers and distribute products fast and relatively at low cost especially by using the internet[13]. Further the close relationship building that network marketers focus on and develop with their customers enhances the concentrated efforts and activities within certain social groups, regional, religious, or ethnic community groups. For example, Amway's Malaysian network marketing operations grew stronger in the 
minority Chinese community compared to other groups[14].

The unique characteristic of cross-cultural appeal of the network marketing channel is another strong contributing factor for its widespread success[13,15]. It has universal appeal and works in a variety of cultures. Amway's strategies exhibited remarkable success in Japan where extended family relationships and lifelong close relationships seemed to be specifically well suited to the direct marketing methods employed by the company[14]. Further, a "retail revolution" took place in a country like Japan that enhanced network marketing strategies[16]. More Japanese women were employed in the workforce leading to less shopping hours available, and more of the younger people bought products based on trust very typical of the network marketing channel. Also, more people were willing to experiment with newer shopping ways such as direct marketing, and a greater number of the aging population was looking for convenience in shopping perhaps from home.

Further, the entrepreneurial spirit that network marketing encourages seems appealing to many who are interested in the independent entrepreneurial activities outside of the traditional business settings[17]. Many middle-aged Japanese managers as well as managers from other nationalities in many parts of the world are looking for independence from the typical employer-employee relationship at work and are venturing out on their own exploring non-traditional self-managed businesses, and network marketing provides a very viable opportunity in this area. When a firm uses a variety of effective network marketing strategies as tools of distribution and combines these with sustainable supply chain management activities in the supply chain, it is more likely to move toward achieving effective operations management and sustainability.

\subsection{Significance of Supply Chain Management}

Effective supply chain management or sustainability in supply chain networks focuses on a sequence of organizations including their facilities, activities, and functions all integrated toward efficient production and delivery of products and services continually over a long period of time. Sustainability should be measured by not only profits but also by the impact of the supply chain on ecological and social systems[18]. An organization that performs well should be focused on doing well on the traditional profit and loss measure as well as on the expanded conceptualization of performance which includes social and environmental dimensions. This is often referred to in the supply chain literature as the triple bottom line[19].

According to the literature on sustainability and supply chain management, the triple bottom line is affected by three major factors - existing best practices, supply chain strategy, and integration. Several studies have shown a connection between existing best practices in supply chain management and environmental outcomes and practices. Positive relationships have been found between TQM[20] and JIT[21] and environmental outcomes. Major best practices on sustainable supply chain management include col- laborations between supply chain members, cooperation with suppliers, and certifications. Collaborative behaviors between suppliers and customers can enhance the environmentally sustainable supply chain[22,23]. Some practices that promote collaborative behaviors include incentives for suppliers to reduce their risk for trying novel collaborative practices required for the sustainability in the supply chain[24]. Another good practice behavior is the sharing of knowledge and educating one another by the firms with their suppliers and these suppliers should educate other suppliers within their supply chain[25]. Supplier certification, which denotes higher levels of quality, is yet another good practice behavior that promotes sustainable supply chain management[26].

Also, supply chain strategy has a major impact on supply chain sustainability. Literature studies have showed the use and significance of an ecocentric perspective for achieving sustainability -- referring to the organization's ability to adapt well to its social and natural environments[27]. The more flexible and adaptable the organization to its environment, the better the potential toward supply chain sustainability. This would allow the organization to include nongovernmental agencies, community groups and agencies, and sometimes even competitors that traditionally have been ignored. Collaborations amongst various members including non-traditional members in the supply chain would enhance the supply chain sustainability[28]. Also, the use of innovation by a firm as a strategic option would enhance sustainability. Sometimes, a firm can be innovative and adopt a service oriented strategy and provide more than the minimum level of service that it used to traditionally provide. For example, some chemical suppliers offer chemical management services to other companies in the supply chain[29]. They work with the buying firms and provide some additional services such as helping design the production facility, facilitating with delivery and handling of materials, and maybe help even with waste treatment. So the supply chain members are more like partners in a now new mutually beneficial relationship all working together to enhance sustainability for the entire supply chain.

Another factor that enhances sustainability in the supply chain is the integration of sustainability goals, practices, and attitudes into day to day activities of supply chain management. Sustainability is everyone's responsibility within the supply chain starting from the top management of every firm. Firms that show a proactive stand toward the environment become more sustainable[30]. Further, top management must show a strong commitment along with taking a proactive stand toward sustainability, which often gets implemented as a written environmental policy[31]. Other factors that would promote sustainability include improved measurement and design processes. Effective supply chain managers would design improved measurement processes that show a connection between certain behaviors and desired outcomes leading to rewards that employees place high values on. These would motivate employees toward improved performance as well as achieve sustainability 
goals and processes. Similarly, redesigning the products and processes to eliminate or reduce pollution has shown improvements in plant performance[30]. It all begins with top management willing to provide a strong commitment to achieving sustainability in the supply chain. This may be enhanced with the redesigning of products and processes geared toward sustainability. And sustainability may be made possible only with the cooperation of all employees, who would get involved if motivated properly with the appropriate, relevant, and attractive incentives that they value. Therefore, sustainability or effective supply chain management together with network marketing may be blended together in and by an organization to achieve positive outcomes, specifically customer satisfaction and loyalty as illustrated in Figure 1 in the following section.

\section{Network Marketing-Supply Chain Integration Model (NM-SCI)}

The manufacturer makes a conscious decision to specifically choose the network marketing strategy and/or distribution channel because of the multiple advantages including one-on-one personalized touch between distributor and customer; the huge cost benefits to the manufacturer in employing this distribution structure; the capital requirement and cash flow advantages; more control and quicker action in terms of communication, promotions, new product introductions, etc.; excellent coverage related to maximizing sales volume, market share, and market penetration; its cross cultural appeals that enables targeting wider expanded markets; and the entrepreneurial spirit that is encouraged amongst the distributors. All these advantages lead toward motivating stronger performance from the distributors and also enhance the manufacturer-distributor relationships. The sustainable supply chain management strategies that are recommended in this model include: top management commitment, design innovation, creativity and flexibility, supply chain integration and efficiency, overall supply chain cost reduction, and effective flow management.

For sustainable supply chain management at a firm, top management has to be proactive and also needs to provide support and commitment to the supply chain activities[30]. Commitment and proactive orientation would be established through the integration of economic and noneconomic aspects of sustainability. Environmental and social goals have to complement and tie-in with the economic goals and activities such as revenue generation and profits and marketing, communication, distribution, etc. Further, proactive orientation would be exhibited through the organizational attitudes toward sustainability at the organization. At proactive organizations, it would be part and parcel of the firm's tasks and activities and the mindset throughout the organization and at all times -- 24/7. All decisions made at the proactive and sustainable organization have to impact the triple bottom line in some way or the other. In addition, a proactive and committed firm would focus on a guiding value or philosophy related to sustainability that would drive the entire organization and its decision making. Then, responsibility for sustainability has to be shared amongst everybody in the supply chain - it has to be a shared responsibility for the whole organization and not any one particular person. This way organizational sustainability is every organizational member's passion - when people have input in the decision making process to achieve and maintain sustainability they are more likely to implement it.

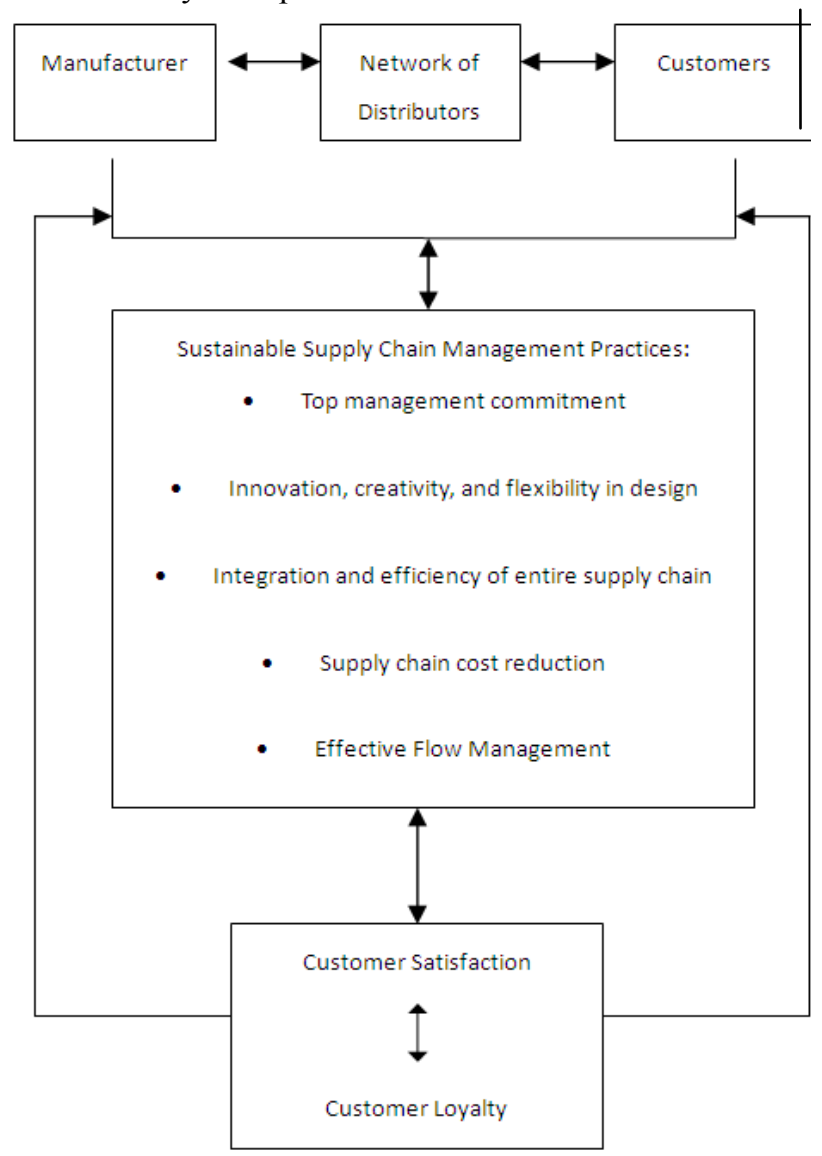

Figure 1. Network Marketing-Supply Chain Integration Model (NM-SCI)

Innovation, creativity, and flexibility in supply chain design would also enhance sustainability. These new practices include traceability and transparency[32]. Traceability is an internal information sharing practice to facilitate supply chain performance and minimize risks in the whole chain. For example, information on ingredients or materials used in the products in the entire chain, including all items that the supplier bought, have to be provided and traced to the source to ensure meeting specifications and standards of quality and other aspects. Transparency refers to the access/information provided on the flow of money and all related activities such as profitability throughout the supply chain. Sustainability would be enhanced through information sharing via transparency and traceability in the entire supply chain[33].

Sustainability would be also improved through integration and efficiency of the supply chain by use of strategies such as maintaining supplier continuity and loyalty. As the Japanese 
supply chain management practices have shown, supplier continuity and loyalty are key trademarks of sustainability[34]. Companies that have continuity in long-term relationships with suppliers tend to improve their efficiency and integration as well as those of the entire supply chain. Sustainable companies focus on treating their suppliers as family members and ensure keeping them successful and staying in business as well as helping them to invest, innovate, and grow. Long-term and continuous supplier partnerships implies fewer reliable suppliers, long-term relationships, continuity, loyalty, sharing of information, and cooperation in planning all of which contribute toward sustainability of both the firms and their suppliers in the supply chain. Further, supplier continuity reduces supplier risks and offsets higher costs as supply chain members help each other and ensure reliability in the supply chain. Local firms close to the manufacturer are also supported and encouraged via long-term contracts and relationships through these supplier continuity strategies thus providing mutual benefits to the manufacturing firms and their suppliers. Sustainability would be enhanced through supplier certification also. Supplier certification such as the ISO 9000, the most widely used international certification, provides often the status of world class suppliers to firms that obtain this certification. A major advantage of using certified suppliers is that the buying firms can eliminate all or most of the inspection and testing costs of delivered goods, thus benefitting from lower costs of inspection and testing as well as saving on time. Rather than checking and testing the supplies after they arrive, the manufacturing firm can straightaway use the items in their production processes when these have arrived from a certified supplier. Honda Motors and Toyota use certified suppliers for many components used in their respective production plants and both manufacturers benefit tremendously especially in terms of lower costs from such an arrangement.

Another supply chain practice that promotes sustainability would be the implementation of cost reduction strategies and trade-offs when structuring a supply chain[35]. Lot size-inventory trade-off, when managed well, can lower the overall cost for the suppliers and the firms. Large production volumes or ordering large lots provide benefits in terms of quantity discounts and lower setup costs; however, the carrying costs are higher for suppliers who carry these large inventories. An optimal trade-off here can benefit both suppliers and firms. Similarly inventory-transportation costs trade-off has to be balanced. Suppliers prefer to ship large full truckloads to optimize their costs, but this leads to higher costs for customers. Optimizing solutions include combining several orders, decreasing truckload capacity, and the cross-docking strategy, where storage at the warehouse is eliminated thereby incurring zero storage costs. Several companies including Wal-Mart have used this cross-docking strategy to offset transportation and storage costs. Lead time-transportation cost trade-offs are enhanced through improved forecasting information to suppliers which helps them in turn improve the timing of their production and orders to their suppliers. Product variety-inventory trade-off may be optimized through delayed differentiation, which offsets the higher costs associated with product variety. Instead delayed differentiation minimizes production costs through adopting standardization, rather than product variety and customization, in the production process. Similarly cost-customer service trade-off may be influenced by shipping directly from warehouse to customer by-passing the retail store. This saves on lead time and reduces storage costs although it may increase transportation costs. Overall though, the costs are optimized.

Further, to promote effective flow management, just-in-time methods may be employed that also enhance sustainability in the supply chain. Product and service need to flow smoothly in the supply chains, information has to freely and quickly flow between and within channels, and timely financial related arrangements should also flow well and be easily accessible. Product and service flow include goods and services from suppliers to customers and the effective handling of customer needs and product returns. Information flow refers to the sharing of forecast and sales data, and the tracking and updating of orders and shipments. Financial flow includes credit terms and payments, and other consignment and title ownership related arrangements. Dell Computers, for example, uses lean manufacturing, a just-in-time method, to maintain smooth flow and sustainability in its supply chain. In its lean manufacturing, Dell uses the tiered approach in terms of its suppliers which means rather than buying from hundreds of suppliers, it buys from a small number of suppliers. The company works with few first-tier suppliers who work directly with the company or who supply major subassemblies. The first-tier suppliers take responsibility for managing their second-tier suppliers who supply the components for the subassemblies, thereby avoiding the final buyer, Dell, from dealing with many suppliers. This type of a just-in-time structure enhances flow management, speed of delivery, quick and smooth flow of materials and information, efficiency, zero or little inventory, lower optimal costs, improved quality, and overall increase in productivity and benefit to the entire supply chain.

The effective network marketing-sustainable supply chain management integration model has implications on several outcomes such as efficiency, profitability, growth, customer satisfaction, and customer loyalty. When an organization integrates and includes newer, current marketing strategies like viral marketing and social media networking, leveraging the consumers' connections and relationships would be strengthened leading to positive and stronger impact on the mentioned outcomes[7,8]. This study would focus especially on customer satisfaction and customer loyalty - two interactive, essential elements for continuous and repeated business that contributes to overall performance, profits, and growth[36]. Effective and strong customer satisfaction enables repeat business and multiple orders, which when continued for long time would result in strong customer and brand loyalty, and vice versa. These are further enhanced due to the strong relationships developed between manufacturers, suppliers, distributors, and customers through effective 
network marketing. This integrated relationship marketing is well illustrated in practice by the Coca Cola Company. The world famous soda company has successfully maintained for a long time its major strength, a strong distribution excellence, which it achieves through providing excellent customer/client satisfaction directly and indirectly to its customers. Strong customer satisfaction is generated by providing one-on-one personalized service to its direct customers and intermediaries - its highly trained network marketing professionals and relationship building experts such as wholesalers and retailers -- who are in constant close touch at the local levels with their final customers and end users. These strategies emphasize company focus on customer service, customer satisfaction, personal stake, and sincere interest in the customer, which customers are looking for in today's business environment. Such a customer-oriented focus and ongoing strong customer service gives Coca Cola the distinctive competency and edge to say ahead of the competition.

The customer satisfaction and loyalty relationship has been also illustrated at Chick-fil-A, a leading fast-food chicken franchise in the country. The turnover rate for operators at this chain is five percent a year in an industry which has about 40 percent turnover rate. The managers working here are proud of the way they treat their employees and consider themselves to be very successful, compared to their competition like McDonalds and Burger King, despite working six days a week (Chick-fil-A is closed on Sundays due to religious reasons). Customer satisfaction and loyalty leaders like Chick-fil-A, The Vanguard Group, and Enterprise Rent-A-Car all have grown more than double the rate of their competition and enjoy a 15 to 20 percent cost advantage which further enhances their growth and profit potential[34]. So, the economics of customer satisfaction and loyalty are tremendously powerful in any industry. It is simple economics though - customer satisfaction leads to repeat customers, and when done for long time lead to customer loyalty, and repeat satisfied, loyal customers mean more sales and revenue, which would then lead to more profits and growth. What affects customer satisfaction and loyalty? Good customer service drives good customers to become loyal repeat customers and these repeat customers influence their friends and others to become customers too. Network marketing together with sustainable supply chain management practices lead to customer satisfaction and loyalty. Reichheld has recommended some ways toward building customer satisfaction and loyalty which many successful companies follow all or most of them[36]. One such way includes win-win strategies and solutions - a company has to find processes, strategies, and solutions aimed at mutually beneficial outcomes for itself and its customers. Dell exemplifies this win-win strategy. Dell provides some unique customer services such as bundling software together and making it available by shipping directly to the customer's desk; and through offering Premier Pages which provides corporate accounts and their organizational personnel a direct access to online information for delivery related information.
Another way suggested is to be selective with the customers. Loyalty leaders cannot possibly give the world's best value to everyone as this is almost impossible to do so. Enterprise Rent-A-Car illustrates this strategy. The average rental cost for a car at the airports from Enterprise was about half the price charged by its leading competitors like Avis and Hertz[36]. Yet, Enterprise is a leader in its market! This is possible due to its strategy of focusing on special agreements Enterprise has made with selective customers like State Farm Insurance and its clients, who due to prior good experience with Enterprise will give the company the first try. This facilitates growth for the company through its selective efforts and loyal customers. Another loyalty strategy is making the business simple and flexible for customer service and transactions. Size of the team structure seems to be a big factor for company flexibility. For Enterprise, Vanguard, and eBay, the ideal team structure seems to be around seven to ten people - many of their competitors are structured larger and seem inflexible. Across these successful companies, the relatively small team size seems to make a positive contribution toward customer loyalty.

Customer satisfaction and loyalty-building companies also use sensible and motivating incentives and rewards to enhance customer satisfaction and loyalty in customers and employees. Unlike some companies that often try to attract new potential customers by offering them all kinds of incentives while ignoring their loyal customers (as they are hooked already or trapped), some innovative loyalty leaders like The Vanguard Group does just the opposite. Vanguard rewards its 10 years+ loyal customers by offering them some incentives including cutting their prices by one-third and other better deals more so to their loyal customers than to their short term customers.

Also, another innovative strategy focuses on open, direct, communication between customers who help one another share more information about the products and/or company and who interact with one another to solve the same or related problems affecting them. Cisco Systems, eBay, Microsoft and others all offer open communication message boards or similar platforms for their customers to interact, discuss, listen and talk with one another - this novel approach seems to enhance customer satisfaction and loyalty amongst their customers especially as all this communication most often is free, current, updated, and available online. Further, companies must not only practice what they preach, but also preach what they practice. They must communicate to their loyal customers what they are loyal to - core values, principles, mission, vision, etc. and run their business according to what they have stated as their guiding principles. Most successful companies including Chick-fil-A, Hobby Lobby, Southwest Airlines, Enterprise, etc. all follow this strategy.

Reichheld also pointed out that companies need to focus on the "promoters" type of customers[36]. These are the loyal customers who come back as repeat customers. For McDonalds, 80 percent of their sales revenue is obtained from 20 percent of their loyal repeat customers who eat at 
their restaurants at least three times or more per week. The "undecideds" and the "passives" and the "detractors" types of customers (all of whom do not help the company much) should be as minimal as possible for the company. And the bottom line is that company growth is enhanced when the company has more "promoters" than its competition - more long-term repeat customers would lead to higher loyalty, thus leading to higher sales, revenue, profits, and growth.

Some examples of progressive companies using variations of network marketing and sustainable supply chain management practices include Continental Power Corporation (CPC) based in Pennsylvania, and Vollara, based in Dallas, Texas. CPC, a partial network marketing company with one level of authorized distributors, is an environmentally conscious "green" company. It manufactures and markets commercial, residential, and industrial electrical products that improve the efficiency of the electrical system, protect against spikes and surges, and reduce electrical noise thereby prolonging the life of the devices (Personal interview with Allen Johnston, Vice President, Continental Power Corporation, Sept. 2010). CPC has installed one half million systems nationwide and provided reduction of the consumption of electricity saving 42,250 tons of coal, 231,500 barrels of oil, $940 \mathrm{M} \mathrm{cu} \mathrm{ft}$ of natural gas, reduced the emission of 221,500 pounds of sulphur dioxide, 42,000 pounds of nitrous oxide, and 98,350 tons of carbon dioxide (Allen Johnston, 2010). CPC uses sustainable supply chain practices such as being environmentally proactive pursuing environmental, social, and economic goals and a variation of just-in-time distribution system where large customized product systems are built on demand, usually within two weeks of receiving the order from the commercial client.

Vollara, another environmentally conscious "green" company, produces and markets through the network marketing model a variety of environmental and healthy living products including air purifiers, water purifiers, laundry purifiers, and nutritional supplements[37]. Vollara uses a variation of network marketing-supply chain management system to distribute its innovative products directly to the consumers. Its other unique practices include providing rapid and almost instant delivery, excellent customer service, quality products and services, building customer loyalty and strong interpersonal relationships with customers and consumers. Vollara also seeks environmental, social, and economic goals and focuses on activities that enable it to be a socially responsible company. In 2001, its pre-merger partner company, EcoQuest International, exhibited corporate social responsibility by donating several air purifier units that were used to help in the clean-up operations after 9/11 by the Department of Defense and other US government agencies[38].

\section{Solutions and Recommendations}

To maximize effectiveness of this model, a stronger integrative approach is necessary between the network market- ing strategy and the supply chain. More cooperative efforts, coordination, and working together would be necessary for the whole benefit of the entire network marketing organization and all of the supply chain members. Further, a constant monitoring and evaluation system to ensure accountability and responsibility of all members in the entire model are essential to ensure smooth functioning of the whole system and to maintain sustainability in it. Also, effective leadership must be provided usually by the manufacturer to promote sustainability of the model. The larger the organization becomes, it is more complex to manage it effectively, especially in a cross-cultural and global context. It is highly recommended that such a large manufacturer/network marketing organization adopt some type of enterprise resource program (ERP) software such as SAP in order to manage effectively the whole realm of all operations across the world. Enterprise resource programs help coordinate and integrate all functions and divisional units of the large organization and help promote improved decision making, communication, information-sharing, productivity, and growth.

\section{Future Research Directions}

As this paper focused on a theoretical model of network marketing-supply chain management, it is suggested that future research studies may wish to focus on empirically testing this model fully or at least major aspects of it. Also, testing this model in different global settings may provide a more comprehensive understanding of the model and its applications in cross-cultural contexts. It would also provide a more logical rationale for generalizing the conclusions and implications of the model discussed in this study.

\section{Conclusions}

In conclusion, this paper has looked at the effective network marketing-sustainable supply chain management model and its implications for organizations especially in terms of customer satisfaction and loyalty. Using some unique and innovative strategies in network marketing blended together with some sustainable supply chain management practices, an organization can pursue environmental, social, and economic goals which lead to significant and strongly desired outcomes such as customer satisfaction and customer loyalty. Positive and strong customer satisfaction and customer loyalty, in turn, would impact the manufacturer-network marketing channel-customer chain thereby providing a continuous improvement aspect to the model. This study has shown that network marketing and supply chain management are here to stay!

\section{Key terms and Definitions}

Network marketing: also more commonly referred to as direct sales or direct marketing or multilevel marketing 
and/or other similar concepts, is basically the direct distribution strategy of a product or service from the company to the consumers through building effective relationship marketing between distributors and customers.

Sustainable Supply Chain Management: Effective supply chain management or sustainability in supply chain networks focuses on a sequence of organizations including their facilities, activities, and functions all integrated toward efficient production and delivery of products and services continually over a long period of time. Sustainability should be measured by not only profits but also by the impact of the supply chain on ecological and social systems.

Customer Satisfaction: the degree to which the customer perceives his/her expectations are met by the product or service. Higher the expectations met, higher the customer satisfaction.

Customer Loyalty: the degree to which the customer perceives satisfaction with product or service; focus is on attracting the right customers, influencing them to buy, making repeat customers who buy often, buy in higher quantities, and to bring in even more customers.

\section{REFERENCES}

[1] M. Woodburn, M, "Tapping the Network Marketing Model," Direct Marketing Association, Direct Marketing, October, pp. $1-4,2003$

[2] Y. Imura, "Meet the New Paradigm: Network Marketing in Japan. Can American Style Marketing Work in Japan?" Japan Inc Communications, J@pan Inc., November, pp. 38-44, 2004.

[3] R. Rayasam. "Selling, Beijing's Way." U.S. News and World Report, U.S. News and World Report, vol. 142, no. 8, pp. 52-53, 2007.

[4] Online avail: http://www.dsa.org/pubs/numbers/\#SALES.

[5] Online avail: http://www.dsa.org/aboutselling/benefits/.

[6] D. Duffy, "Direct Selling as the Next Channel." Emerald Group Publishing Limited, The Journal of Consumer Marketing, vol. 22, no.1, pp. 43-46, 2005.

[7] Z. Katona, P. Zubcsek, M. Sarvary, "Network Effects and Personal Influences: The Diffusion of an Online Social Network" American Marketing Association, Journal of Marketing Research, vol. 48, no. 3, pp. 425-443, 2011.

[8] Zeisser, M, "Unlocking the Elusive Potential of Social Networks, McKinsey Quarterly, no. 3, pp. 28-30, 2010.

[9] Cateora, International Marketing, $7^{\text {th }}$ ed. Irwin \& Co., USA, 1990.

[10] R. Croft, H. Woodruffe, H, "Network Marketing: The Utimate in International Distribution?" Taylor \& Francis Group, Journal of Marketing Management, vol.12, pp. 201-214, 1996.

[11] R. Eisenberg, "The Mess called Multi-Level Marketing," Money, Money, vol.16, no. 6, pp. 136-160, 1987.
[12] J. Kaikati, “Don't Crack the Japanese Distribution System Just Circumvent it," Elsevier Inc., Columbia Journal of World Business, vol. 28, no. 2, pp. 34-45, 1993.

[13] H. Weitzen, "Billion-dollar growth," Success Media, Success, vol.40, no. 3, p.14, 1993.

[14] Amway, "Prospectus for the Issues of 10,000,000 American Depository Shares Amway Japan Limited," Morgan Stanley \& Co, 1993.

[15] M. Yarnell, "Worldwide Boom," Success Media, Success, vol. 41, no. 2, p.23, 1994.

[16] N. Sanghavi, "Non-store Retailing in Japan: A Huge and Potentially Lucrative Market," Emerald Group Publishing Limited, International Journal of Retail and Distribution Management, vol.18, no.1, pp.19-23, 1990.

[17] G. Gabriel, "Land of Rising Profits," Success Media, Success, vol. 40, no. 2, p. $14,1993$.

[18] P. Jennings, P. Zandbergen, "Ecologically Sustainable Organizations: An Institutional Approach," Academy of Management, Academy of Management Review, vol.20, no.4, pp. 1015-1052, 2005.

[19] P. Kliendorfer, K. Singhal, L. Van Wassenhove, "Sustainable Operations Management," Production Operations Management Society, Production and Operations Management, vol. 14, no. 4, pp. 482-492, 2005.

[20] D. Clark, D, "What Drives Companies to Seek ISO 14000?" BNP Media, Pollution Engineering, pp. 14-15, 1999.

[21] A. King, M. Lenox, "Lean and Green? An Empirical Examination of the Relationship Between Lean Production and Environmental Performance," Productions and Operations Management Society, Productions and Operations Management, vol.10, no. 3, pp. 244-256, 2001.

[22] C. Carter, J. Carter, "Interorganizational Determinants of Environmental Purchasing: Initial Evidence from the Consumer Products Industry," Decision Sciences Institute, Decision Sciences, vol. 29, no. 3, pp. 659-695, 1998.

[23] Q. Zhu, J. Sarkis, "Relationships between Operational Practices and Performance Among Early Adopters of Green Supply Chain Management Practices in Chinese Manufacturing Enterprises," Elsevier Inc., Journal of Operations Management, vol. 22, pp. 265-289, 2004.

[24] A. Goodman, "Implementing Sustainability in Service Operations at Scandic Hotels," INFORMS, Interfaces, vol. 30, no. 3, pp. 202-214, 2000.

[25] P. Rao, D. Holt, "Do Green Supply Chains Lead to Economic Performance?" Emerald Group Publishing Limited, International Journal of Operations and Production Management, vol. 25, no. 9, pp. 898-916, 2005.

[26] P.Tuescher, B. Gruninger, F. Ferdinand, "Risk Management in Sustainable Supply Chain Management (SSCM): Lessons Learnt from the Case of GMO-Free Soy beans," John Wiley \&Sons, Inc., Corporate Social Responsibility and Environmental Management, vol. 13, pp. 1-10, 2005.

[27] S. Seuring,"Integrated Chain Management and Supply Chain Management Comparative Analysis and Illustrative Cases," Elsevier, Inc., Journal of Cleaner Production, vol.12, pp. 1059-1071, 2004. 
[28] T. Johnston, H. Linton, "Social Networks and the Imple mentation of Environmental Technology," IEEE, IEEE Transactions on Engineering Management, vol. 47, no. 4, pp. 465-477, 2000.

[29] S. Sharma, I. Henriques, "Stakeholder Influences on Sustainability Practices in the Canadian Forest Products Industry," Strategic Management Society, Strategic Management Journal, 26, pp. 159-180, 2005.

[30] R. Klassen, D. Whybark, D. "Environmental Management in Operations: The Selection of Environmental Technologies, Decision Sciences Institute, Decision Sciences, vol. 30, no. 3, pp. 601-631, 1999.

[31] C. Ramus, U. Steger, "The Role of Supervisory Support Behaviors and Environmental Policy in Employee "Ecoinitiatives' at leading Edge European Companies, Academy of Management, Academy of Management Journal, vol. 43, no. 4, pp. 605-628, 2000.

[32] A. Roth, M. Pullman, J. Gray, J. "Unraveling the Food Supply
Chain: Strategic Insights from China and 2007 Recalls," John Wiley \&Sons, Inc., Journal of Supply Chain Management, vol. 44, no. 1, pp. 22-39, 2008.

[33] H. Lee, S. Whang, "Information Sharing in a Supply Chain," InderScience Publishers, International Journal of Technology Management, vol. 20, no. 3/4, pp. 373-387, 2000.

[34] J. Liker, T. Choi, "Building Deep Supplier Relationships," Harvard Business Publishing, Harvard Business Review, vol. 82, no. 12, pp. 104-113, 2004.

[35] H. Lee, C. Billington, "Managing Supply Chain Inventory," Massachusetts Institute of Technology, Sloan Management Review, Spring, pp. 65-68, 1992.

[36] F. Reichheld, The Ultimate Question; Driving Good Profits and True Growth, Bain and Company, USA, 2006.

[37] Online Available: http://www.vollara.com.

[38] Online Available: http://www.ecoquestintl.com. 